\title{
ALGORITMA MASIH MUSLIATUN (MM) UNTUK MENDUKUNG SISTEM OTOMATISASI PENDAFTARAN PRAKTIKUM DENGAN PENGUJIAN PADA JARINGAN KOMPUTER (STUDI KASUS DI STTA YOGYAKARTA)
}

\author{
Masih Musliatun, Haruno Sajati, Yuliani Indrianingsih \\ Teknik Informatika STTA Yogyakarta \\ Informatika@stta.ac.id
}

\begin{abstract}
Practicum registration systems that exist on campus STTA previously done manually, where students will sign up to the admin to bring proof of payment practicum. Students are free to choose his own class, this often resulted in unbalanced number of students in the classroom lab that is considered less effective way. This makes the emergence of the idea to establish an MM algorithm is applied to a practical application of automation systems. MM algorithm works by determining many lab classes based on students who took the KRS. Furthermore, students who have paid practicum will be immediately incorporated into the classes that are available with regard to the number of students and GPA of students per class, so it will obtain practical classes by the number of students and the average GPA of each class balanced. Concept application using client-server database, where the database is on the Local Area Network (LAN) STTA. To facilitate the management admin, then the application will be tested on the LAN network and VPN (Virtual Private Network) network. LAN is a computers network that are connected to a computer server by using specific topologies, typically used in areas of the building or area a distance of not more than $1 \mathrm{~km}$ (local area). While VPN is a secure way to access the Local Area Network that is in range, using the Internet or other public network to perform packet data transmission in private. By using a VPN, users can access the computer that is on the LAN even though the user is not in the same location with a LAN.
\end{abstract}

Keywords: Algorithms MM, Local Area Network, Virtual Private Network

\section{PENDAHULUAN}

Pendaftaran praktikum di kampus Sekolah Tinggi Teknologi Adisutjipto Yogyakarta selama ini masih dilakukan secara manual. Mahasiswa yang telah mengambil mata kuliah praktikum pada saat pengisian Kartu Rencana Studi (KRS) harus mendaftarkan dirinya kembali pada kelas praktikum ke pihak laboran dengan membawa bukti pembayaran praktikum. Permasalahan yang sering muncul yaitu banyak mahasiswa yang terlambat mendaftar kelas praktikum, yang kemungkinan disebabkan karena kurangnya informasi. Selain itu dapat pula menyebabkan overload mahasiswa pada kelas praktikum, serta tidak seimbangnya pendistribusian mahasiswa pada tiap-tiap kelas praktikum yang menyebabkan tidak efektifnya kegiatan praktikum. Kedua faktor tersebut dapat dikarenakan mahasiswa diberi kebebasan dalam memilih kelas praktikumnya.

Hal inilah yang membuat munculnya ide untuk menciptakan algoritma Masih Musliatun (MM) untuk mendukung sistem otomatisasi pendaftaran praktikum. Penerapan sistem 
tersebut akan menggunakan jenis database client-server, dimana aplikasi dan database berada pada komputer yang terpisah. Database berada pada komputer server (jaringan lokal kampus) dan aplikasi berada pada komputer user (admin). Oleh karena itu, dibutuhkan jaringan komputer untuk mengakses sistem yang tentunya mendukung kemudahan akses bagi user, sehingga dilakukan pengujian penerapan sistem tersebut pada jaringan Local Area Network (LAN) dan Virtual Private Network (VPN).

\section{LANDASAN TEORI}

\subsection{Tinjauan Pustaka}

a. The Northwest Corner Rule

The Northwest Corner Rule merupakan suatu metode dari John D. Merritt pada tahun 2000 yang bertujuan untuk menemukan solusi dasar dan layak untuk mengatasi masalah transportasi.

b. Sistem Pendukung Keputusan Penjadwalan Mata Kuliah dengan Metode Simple Additive Weighting.

Dalam perancangan dan pembuatan sistem ini terdapat penelitian pada skripsi terdahulu yaitu karya Witty Novida Nainggolan yang membahas tentang Sistem Pendukung Keputusan (SPK) penjadwalan mata kuliah yang menghasilkan keputusan jadwal yang tidak berbenturan antara masing-masing dosen dan cukup membantu dalam proses penjadwalan mata kuliah.

\subsection{Algoritma MM}

Algoritma MM merupakan algoritma baru yang diciptakan untuk menyeimbangkan atau membagi rata data praktikum, dengan sistem otomatisasi berdasarkan kriteria jumlah mahasiswa dan nilai IPK mahasiswa. Algoritma ini bekerja dengan menginputkan data tersebut secara berulang ke dalam wadah (kelas) yang tersedia berdasarkan jumlah mahasiswa dan nilai IPK mahasiswa. Diharapkan dengan terciptanya algoritma MM dapat dicapai hasil yang merata \& seimbang pada setiap kelas/wadah yang tersedia.

\subsection{Pengertian Jaringan LAN dan VPN}

Local Area Network (LAN) merupakan jaringan komputer yang saling terhubung ke suatu komputer server dengan menggunakan topologi tertentu, biasanya digunakan dalam kawasan satu gedung atau kawasan yang jaraknya tidak lebih dari $1 \mathrm{~km}$.

VPN adalah singkatan dari virtual private network, yaitu sebuah cara aman untuk mengakses local area network yang berada pada jangkauan, dengan menggunakan internet atau jaringan umum lainnya untuk melakukan transmisi data paket secara pribadi. Melalui VPN, seolah-olah user/admin yang menjalankan aplikasi sedang berada di jaringan (localhost) yang sama dengan server database walaupun sesungguhnya user/admin sedang berada pada jaringan internet (public), sehingga dapat meningkatkan keamanan data karena data tidak bisa diakses pada jaringan public. 


\section{Perancangan Algoritma}

Algoritma MM merupakan singkatan dari nama penciptanya yaitu Masih Musliatun. Algoritma ini diterapkan dalam bahasa pemrograman Delphi untuk mendukung sistem otomatisasi pendaftaran praktikum. Algoritma MM yaitu suatu algoritma baru yang diciptakan untuk menyeimbangkan atau membagi rata data praktikum berdasarkan kriteria jumlah mahasiswa dan nilai IPK mahasiswa. Algoritma ini bekerja dengan menginputkan data tersebut secara berulang ke dalam wadah (kelas) yang tersedia berdasarkan jumlah mahasiswa dan nilai IPK mahasiswa. Pada penerapannya, Algoritma ini dibagi menjadi dua tahap yaitu:

1. Algoritma MM I, pada tahap ini akan diproses banyak siswa yang mengambil praktikum berdasarkan database pada Sistem Informasi Akademik (SIA). Dari data tersebut maka akan dibentuk banyak kelas praktikum yang memungkinkan, dimana untuk menentukan banyak kelas praktikum digunakan rumus perhitungan :

Banyak Kelas $=\frac{\text { Total mhs praktikum }}{20}$ Rumus (1)

Dari perhitungan tersebut akan diperoleh batasan jumlah kelas yang memungkinkan sehingga dapat dibuat jadwal praktikum berdasarkan banyak kelas yang tersedia.

2. Algoritma MM II, pada tahap ini akan dilakukan beberapa proses uji kelayakan untuk memasukkan mahasiswa ke dalam kelas-kelas praktikum yang tersedia. Dengan kriteria pengujiannya yaitu jumlah mahasiswa praktikum pada tiap kelas dan IPK mahasiswa, sehingga diharapkan dapat dicapai hasil yang seimbang pada tiap-tiap kelas praktikum. Pada tahap ini, sistem akan menentukan:

a. Data kuota mahasiswa pada tiap-tiap kelas praktikum

b. Data rata-rata IPK pada tiap-tiap kelas

c. Nilai rata-rata IPK terbesar dan terkecil

d. Menentukan kelas dengan kuota terkecil dan rata-rata IPK nya terkecil

e. Menentukan kelas dengan kuota terkecil dan rata-rata IPKnya terbesar

f. Dan terakhir memasukkan data mahasiswa dengan ketentuan:

Jika IPK mhs $\leq \frac{\text { rata IPK trkcil +rata IPK trbsar }}{2}$ Rumus (2)

i. Jika ya, maka Mahasiswa tersebut masuk ke kelas yang 'Kuota terkecil dan ratarata IPKnya terbesar'.

ii. Jika tidak, maka Mahasiswa tersebut masuk ke kelas yang 'Kuotanya terkecil dan rata-rata IPKnya terkecil'.

\section{Implementasi}

\subsection{Implementasi Algoritma MM I pada Aplikasi}

Pada Algoritma MM I ini diterapkan pada Form Jadwal Praktikum. Pada awalnya admin diminta untuk menentukan Mata Kuliah Praktikum, Kode TA, dan 
Kode Semester. Kemudian ditekan tombol 'OK', ketika tombol 'OK' ditekan, maka akan menghasilkan nilai Jumlah Mahasiswa yang mengambil praktikum dan Jumlah kelas. Jumlah Mahasiswa berasal dari total mahasiswa yang mengambil praktikum berdasarkan database SIA. Hasil penerapan Algoritma MM I terdapat pada gambar 1.

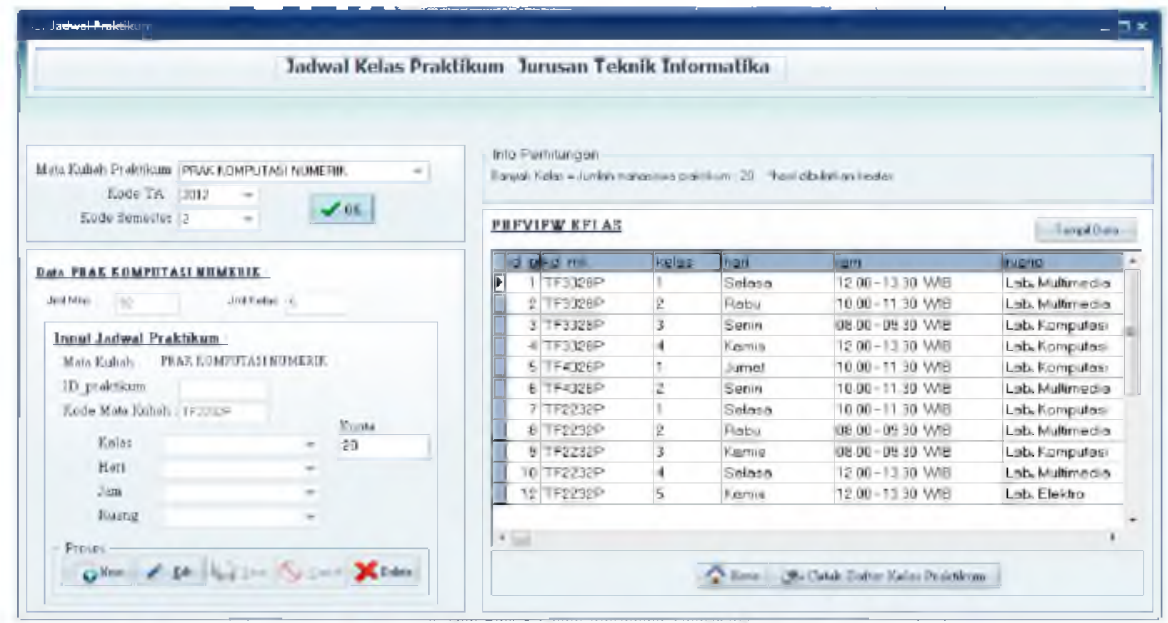

Gambar 1 Implementasi Algoritma MM I

Kode program algoritma MM I diterapkan pada tombol ' $O K^{\prime}$ ' seperti yang terdapat pada gambar 1 dengan menerapkan perhitungan rumus (1) untuk menentukan banyak/jumlah kelas praktikum.

Pada proses sistemnya, admin diminta untuk menentukan Mata Kuliah Praktikum, Kode TA, dan Kode Semester. Kemudian ditekan tombol 'OK', ketika tombol 'OK' ditekan, maka akan menghasilkan nilai Jumlah Mahasiswa yang mengambil praktikum dan Jumlah kelas. Jumlah Mahasiswa berasal dari total mahasiswa yang mengambil praktikum berdasarkan database SIA. Selanjutnya tombol 'New' untuk input data akan otomatis aktif ketika sudah dicapai hasil perhitungan Jumlah Mahasiswa dan Jumlah Kelas, sehingga admin dapat menginputkan jadwal berdasarkan jumlah kelas yang tersedia pada combobox kelas seperti pada gambar diatas.

\subsection{Implementasi Algoritma MM II pada Aplikasi}

Pada Algoritma MM II ini bertujuan untuk memasukkan mahasiswa yang telah lunas membayar praktikum ke kelas-kelas praktikum yang tersedia berdasarkan kriteria jumlah mahasiswa dan IPK mahasiswa. Proses Algoritma MM II ini diterapkan pada dua tombol yaitu tombol 'OK' dan tombol 'Load data Mahasiswa' seperti pada gambar 2 . 


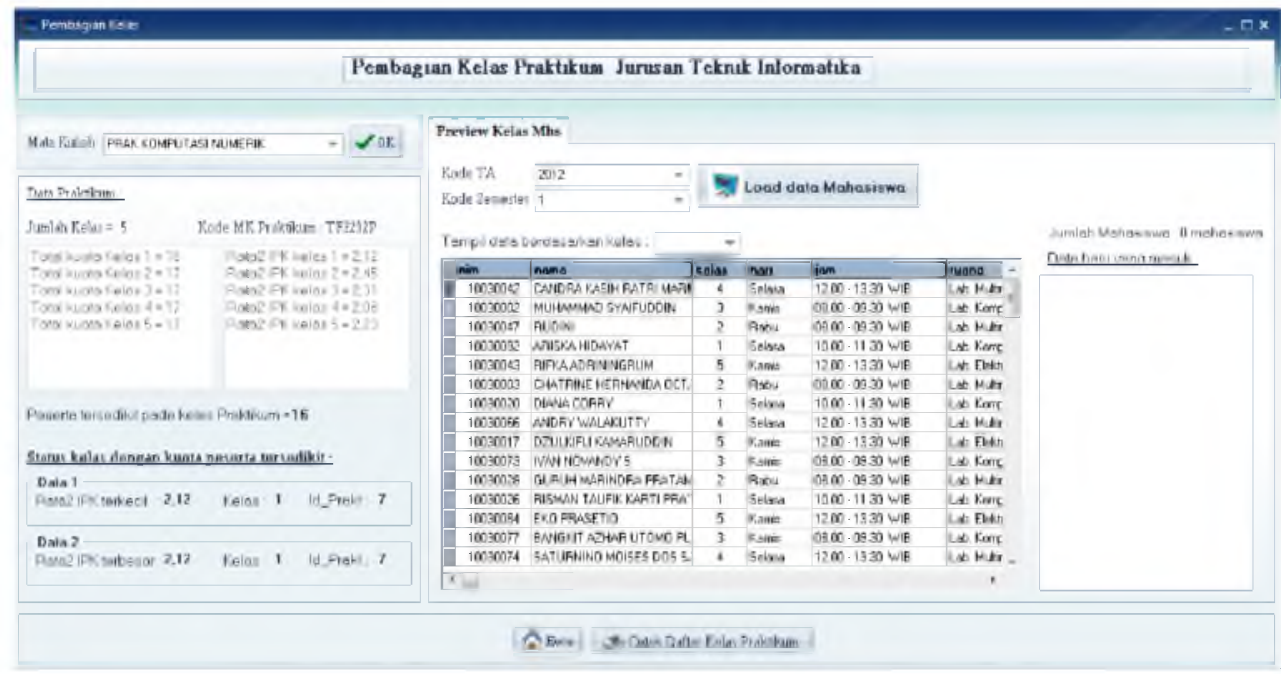

Gambar 2 Implementasi Algoritma MM II

Pada mulanya, admin diminta untuk menentukan mata kuliah praktikum terlebih dahulu, kemudian tekan tombol ' $\mathrm{OK}$ '. Beberapa proses yang dikerjakan oleh tombol 'OK' yaitu untuk menentukan:

a. Data kuota mahasiswa pada tiap-tiap kelas praktikum.

b. Data rata-rata IPK pada tiap-tiap kelas.

c. Nilai rata-rata IPK terbesar dan terkecil.

d. Menentukan kelas dengan kuota terkecil dan rata-rata IPK nya terkecil.

e. Menentukan kelas dengan kuota terkecil dan rata-rata IPKnya terbesar.

Selanjutnya admin harus menentukan kode TA dan kode Semester dari mata kuliah yang dipilih sebelumnya, sehingga sistem dapat mengecek mahasiswa yang mengambil mata kuliah tersebut dan sudah lunas membayar praktikum. Setelah itu, tekan tombol 'Load data mahasiswa'. Sementara untuk proses yang dilakukan pada tombol 'Load data mahasiswa' yaitu untuk menentukan mahasiswa masuk ke kelaskelas praktikum dengan ketentuan seperti pada rumus (2). Dari proses diatas maka akan terjadi proses penginputan mahasiswa ke dalam kelas-kelas praktikum secara otomatis, sehingga akan diperoleh kelas praktikum dengan jumlah mahasiswa dan rata-rata IPK tiap kelasnya merata dan seimbang. Setiap admin menekan tombol 'Load data mahasiswa' maka sistem akan selalu mengecek database, apakah ada mahasiswa yang baru masuk kedalam database. Jika ya, maka sistem akan otomatis memasukkannya ke dalam kelas yang tersedia.

\subsection{Implementasi Aplikasi pada Jaringan LAN}

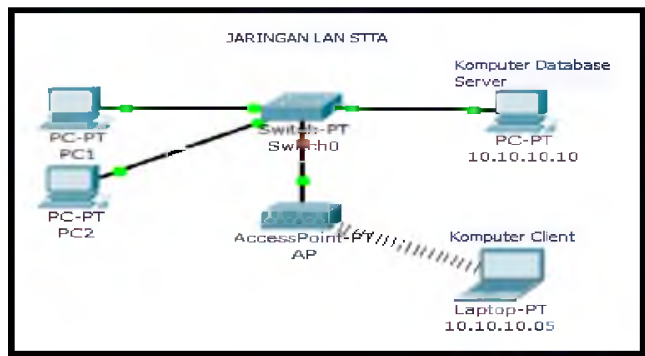

Gambar 3 Jaringan LAN 
Aplikasi diterapkan pada jaringan LAN atau Local Area Network, dimana komputer server database berada pada jaringan STTA dan untuk dapat mengaksesnya, komputer client harus berada pada jaringan yang sama (jaringan STTA). Pada implementasi kali ini, komputer client menggunakan jaringan wifi STTA dengan konfigurasi IP manual seperti pada gambar 4 . Dengan terkoneksi pada jaringan wifi STTA, maka user dapat menjalankan aplikasi serta mengakses database pada komputer server.

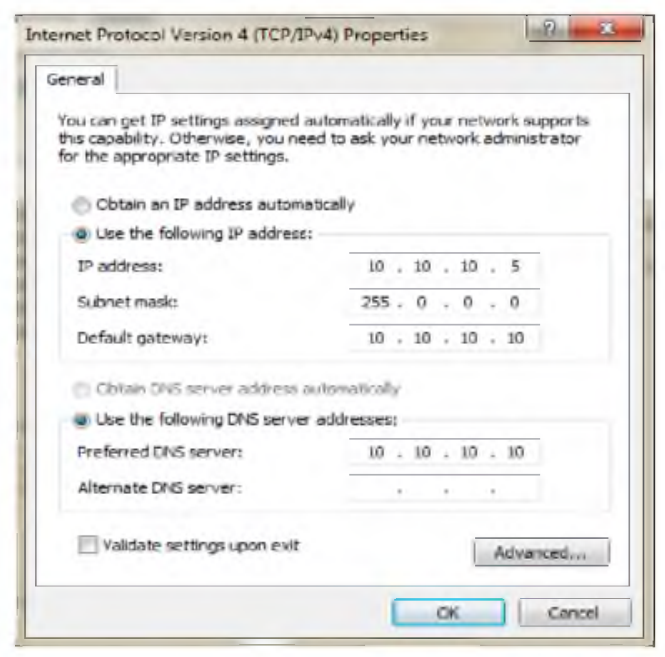

Gambar 4 Konfigurasi LAN

\subsection{Implementasi Aplikasi pada Jaringan VPN}

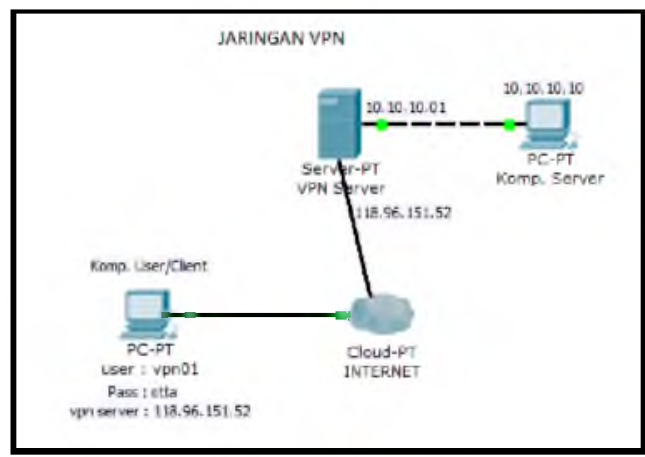

Gambar 5 Jaringan VPN

Dalam penerapan VPN, user harus terhubung terlebih dahulu dengan jaringan public (internet), selanjutnya user harus membuat akses ke VPN pada jaringan STTA. User harus membuat konfigurasi VPN pada komputer yang digunakan seperti berikut:

IP VPN server : 118.96 .151 .52

Username : vpn01

Password : :****

Setelah membuat konfigurasi VPN pada komputer user, maka user tinggal klik connected pada akun vpn yang telah dibuat sehingga akan tampak sepeti gambar 6 . Pada gambar 6 tampak user terkoneksi dengan internet (jaringan public) dan terkoneksi dengan VPN. Setelah dapat terkoneksi ke jaringan VPN STTA, maka user pun dapat langsung menjalankan aplikasi dari mana saja, bahkan bisa dilakukan dari 
rumah sekalipun. Hal ini bertujuan untuk mempermudah user dalam mengakses aplikasi dari mana saja, meskipun sedang tidak berada pada jaringan kampus.

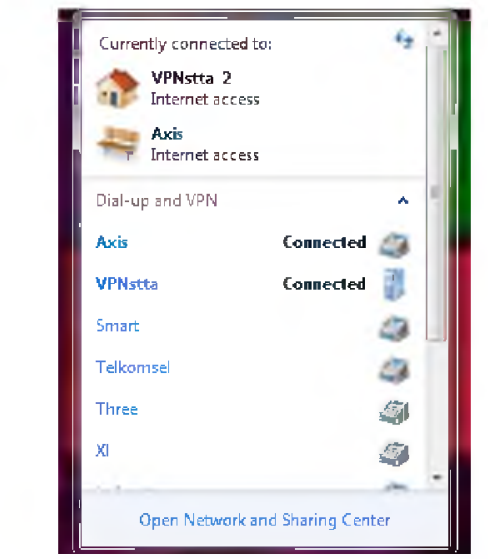

Gambar 6 status koneksi VPN

\section{Analisa}

\subsection{Hasil Pengujian Algoritma MM I}

Tabel 1 merupakan tabel hasil pengujian perhitungan jumlah kelas berdasarkan banyak mahasiswa yang mengambil KRS praktikum:

Tabel 1 Hasil Pengujian Jumlah Kelas

\begin{tabular}{|l|l|c|c|c|c|}
\hline No. & \multicolumn{1}{|c|}{$\begin{array}{c}\text { Mata Kuliah } \\
\text { praktikum }\end{array}$} & $\begin{array}{c}\text { Kode } \\
\text { TA }\end{array}$ & Kode Smt & $\begin{array}{c}\text { Total mhs yg } \\
\text { ambil } \\
\text { praktikum }\end{array}$ & $\begin{array}{c}\text { Hasil } \\
\text { perhitungan } \\
\text { jumlah kelas }\end{array}$ \\
\hline 1. & $\begin{array}{l}\text { Prakt. Komputasi } \\
\text { Numerik }\end{array}$ & 2012 & 2 & 92 & 5 \\
\hline 2. & $\begin{array}{l}\text { Prakt. Jaringan } \\
\text { Komputer }\end{array}$ & 2011 & 1 & 83 & 5 \\
\hline 3. & $\begin{array}{l}\text { Prakt. } \\
\text { Pemrograman } \\
\text { Berorientasi Objek }\end{array}$ & 2011 & 2 & 65 & 4 \\
\hline
\end{tabular}

Berdasarkan data pada tabel 1, maka hasil perhitungan jumlah kelas dengan Algoritma MM I dinyatakan valid karena hasil perhitungan jumlah kelas tersebut memenuhi rumus Algoritma MM I.

\subsection{Hasil Pengujian Algoritma MM II}

Tabel 2 dan tabel 3 merupakan tabel hasil sampel dari pengujian pembagian kelas praktikum menggunakan Algoritma MM II. 
Tabel 2 Pengujian Pembagian Kelas Sampel 1

\begin{tabular}{|c|c|c|}
\hline \multicolumn{3}{|c|}{ PRAKTIKUM KOMPUTASI NUMERIK || } \\
\hline Kelas & Kuota terisi (mahasiswa) & Rata-rata IPK kelas \\
\hline 1 & 16 & 2,12 \\
\hline 2 & 17 & 2,29 \\
\hline 3 & 17 & 2,10 \\
\hline 4 & 17 & 2,23 \\
\hline 5 & 17 & 2,44 \\
\hline
\end{tabular}

Tabel 3 Pengujian Pembagian Kelas Sampel 2

\begin{tabular}{|c|c|c|}
\hline \multicolumn{3}{|c|}{ PRAKTIKUM JARINGAN KOMPUTER || } \\
\hline Kelas & Kuota terisi (mahasiswa) & Rata-rata IPK kelas \\
\hline 1 & 17 & 2,28 \\
\hline 2 & 16 & 1,86 \\
\hline 3 & 16 & 2,19 \\
\hline 4 & 17 & 2,24 \\
\hline 5 & 17 & 2,35 \\
\hline
\end{tabular}

Berdasarkan kedua sampel hasil pengujian pembagian kelas praktikum, maka pembagian mahasiswa otomatis ke dalam kelas-kelas praktikum dinyatakan valid dan seimbang, karena data kuota terisi dan rata-rata IPK antara kelas yang satu dan kelas yang lain memiliki perbandingan yang kecil.

\subsection{Hasil Uji Pengguna}

Uji pengguna dilakukan dengan menggunakan kuisioner kepada admin laboran guna menghasilkan nilai kelayakan aplikasi otomatisasi pendaftaran praktikum ini.

Kuisioner untuk uji pengguna ini menggunakan pertanyaan dan angka sebagai nilainya, angka 5 merupakan angka penilaian paling tinggi. Kuisioner dapat dilihat pada tabel 4 .

Tabel 4 Hasil Kuisioner

\begin{tabular}{|c|l|c|}
\hline No. & \multicolumn{1}{|c|}{ Kriteria Kuisioner } & Nilai \\
\hline 1. & $\begin{array}{l}\text { Interface (Tampilan) } \\
\text { program }\end{array}$ & 4 \\
\hline 2. & $\begin{array}{l}\text { Kemudahan } \\
\text { penggunaan program }\end{array}$ & 5 \\
\hline 3. & Kegunaan program & 3 \\
\hline 4. & $\begin{array}{l}\text { Kejelasan informasi } \\
\text { dan data yang ada }\end{array}$ & 4 \\
\hline 5. & $\begin{array}{l}\text { Penilaian program } \\
\text { secara keseluruhan }\end{array}$ & 4 \\
\hline
\end{tabular}

Berdasarkan hasil kuisioner yang telah dilakukan, dicapai hasil kriteria kuisiner no.1 mendapat nilai 4, kriteria no.2 mendapat nilai 5, kriteria no.3 mendapat nilai 3 , kriteria no.4 mendapat nilai 4, dan kriteria no.5 mendapat nilai 4 . Nilai 5 merupakan 
nilai tertinggi, maka aplikasi ini dianggap sudah memenuhi uji kelayakan untuk diterapkan.

\subsection{Hasil Perbandingan Penerapan Aplikasi Pada Jaringan LAN dan VPN}

Local Area Network (LAN) merupakan jaringan komputer yang saling terhubung dari satu komputer ke komputer lain atau server dengan menggunakan topologi tertentu, biasanya digunakan dalam kawasan satu gedung atau kawasan yang jaraknya tidak lebih dari $1 \mathrm{~km}$. Berdasarkan hasil analisa dalam penelitian ini, diperoleh beberapa kelebihan dari jaringan LAN sebagai berikut:

a. Penggunaan IP lokal jaringan.

b. Pemakaian sumber daya bersama-sama, karena antara client dan server berada pada satu jaringan lokal yang sama.

c. Efektifitas dan Efisiensi kerja lebih produktif.

d. Copy data antar PC menjadi lebih cepat.

e. Proses loading aplikasi menjadi lebih cepat.

f. Hemat biaya. Tidak memerlukan perantara pihak ketiga (Provider lain) untuk koneksi antara aplikasi dan database server.

Namun dari beberapa kelebihan tersebut juga terdapat kekurangan dari jaringan LAN yaitu:

a. Semakin banyak PC yang mengakses jaringan, maka semakin lemot koneksi.

b. Tergantung dari speed server saat itu.

c. Kemungkinan terjadi kepadatan lalulintas data.

d. Harus berada pada lokasi yang sama dengan server (dalam satu gedung).

Jaringan VPN merupakan singkatan dari virtual private network, yaitu sebuah cara aman untuk mengakses local area network yang berada pada jangkauan, dengan menggunakan internet atau jaringan umum lainnya untuk melakukan transmisi data paket secara pribadi. Berdasarkan hasil analisa dan pengujian yang dilakukan pada penelitian ini, diperoleh beberapa kelebihan dari jaringan VPN yaitu:

a. Fleksibilitas, user dapat berada dimana saja tanpa terbatas oleh jarak dan waktu.

b. Kemudahan pengaturan jaringan.

c. Memiliki saluran sendiri, sehingga terhindar dari antrian atau kepadatan jalur.

d. Akses data akan melewati server VPN, sehingga aktivitas komputer dan alamat situs web yang dikunjungi tidak terlihat oleh pihak lain seperti provider yang digunakan.

e. Kecepatan, keamanan dan kestabilan data berbanding lurus dengan harga yang harus dibayar.

Dari beberapa kelebihan tersebut, jaringan VPN juga memiliki kelemahan seperti:

a. Tidak ada kendali utama pengguna.

b. Rawan Penyadapan. Meskipun berada pada saluran pribadi, VPN tetap saja menumpang pada saluran public. Jadi, tidak menutup kemungkinan terjadinya penyadapan.

c. Kestabilan akses sangat tergantung dari provider yang digunakan dan server VPN saat itu.

d. Tergantung pada sinyal atau kekuatan jaringan dari provider dan device (modem) yang digunakan. 
Dari hasil uji coba penerapan aplikasi pada jaringan LAN dan VPN, diperoleh data perbandingan seperti pada tabel 5 .

Tabel 5 Hasil Perbandingan Lama Proses pada LAN dan VPN

\begin{tabular}{|c|c|c|c|c|}
\hline $\mathrm{N}$ & \multirow{2}{*}{ Proses yang dilakukan } & \multicolumn{3}{|c|}{ Lama waktu dalam detik (s) } \\
\hline o. & & LAN & VPN & Selisih \\
\hline 1. & Proses Loading awal program & 7 & 299 & 292 \\
\hline 2. & Proses Load Form & 1 & 1 & 0 \\
\hline 3. & $\begin{array}{l}\text { Proses Algoritma I - Form Jadwal Praktikum: } \\
\text { - } \quad \text { Proses hitung kelas pada tombol 'OK' } \\
\text { - } \quad \text { Proses save, edit, hapus jadwal }\end{array}$ & $\begin{array}{c}1 \\
1,33\end{array}$ & $\begin{array}{c}1,67 \\
1\end{array}$ & $\begin{array}{l}0,67 \\
0,33\end{array}$ \\
\hline 4. & $\begin{array}{l}\text { Proses Algoritma II - Form Pembagian Kelas: } \\
\text { - Proses hitung data pada tombol ‘OK' } \\
\text { - Proses cek data pada tombol ‘Load Data } \\
\text { Mahasiswa' } \\
\text { - Proses hapus data pada tombol 'Hapus Data’ }\end{array}$ & $\begin{array}{c}2 \\
29,67 \\
1,33\end{array}$ & $\begin{array}{c}8,33 \\
622 \\
2\end{array}$ & $\begin{array}{c}6,33 \\
592,33 \\
0,67\end{array}$ \\
\hline
\end{tabular}

Dari tabel 5 diatas dapat disimpulkan bahwa lama proses untuk menjalankan aplikasi menggunakan jaringan LAN lebih cepat daripada menggunakan jaringan VPN. Hal ini kemungkinan dikarenakan karena :

1. Kestabilan speed dan jaringan dari provider yang digunakan.

2. Kestabilan dari server VPN di STTA.

3. Kepadatan lalulintas data pada server.

\section{Kesimpulan}

1. Algoritma MM dapat diterapkan pada sistem pendaftaran praktikum karena proses pembagian kelas dapat dilakukan secara otomatis dan terdistribusi normal.

2. Penerapan sistem pendaftaran praktikum pada jaringan LAN lebih efisien dibandingkan pada jaringan VPN karena aplikasi dapat lebih cepat dalam mengakses database.

3. Penggunaan VPN pada sistem pendaftaran praktikum membuat pihak laboran dapat melakukan perencanaan dan administrasi praktikum dengan lebih efektif.

Saran

1. Aplikasi yang dihasilkan diterapkan untuk semua praktikum pada semua jurusan sesuai dengan kurikulum yang berlaku.

2. Pembagian ruang kelas praktikum disinkronkan dengan pembagian ruang kelas perkuliahan sehingga peserta praktikum dapat memperoleh jadwal kuliah dan praktikum yang baik. 


\section{Daftar Pustaka}

Anonim, 2010, Metode Transportasi. http://ocw.gunadarma.ac.id/course/ industrialtechnology/informatics-engineering-s1/riset-operasional/metode-transportasi, diakses pada tanggal 30 April 2013.

I Nyoman Gede A. Astawa. I Made Ari Dwi S. Atmaja. 2012. Implementasi VPN pada Jaringan Komputer Kampus Politeknik Negeri Bali. Bali : Jurnal Matrix.

Kadir, Abdul. 2005. Pemrograman Database dengan Delphi 7 Menggunakan Access dan ADO. Yogyakarta: Andi.

Kristanto, Andri. 2004. Rekayasa Perangkat Lunak (Konsep Dasar). Yogyakarta : Gaya Media.

Munir, Sirojul. 2005. Aplikasi Server Database PostgreSQL. Jakarta : Dian Rakyat.

Nainggolan, Witty Novida. 2011. Sistem Pendukung Keputusan Penjadwalan Matakuliah Dengan Metode Simple Additive Weighting. Yogyakarta : STTA.

Wahana Komputer. 2003. Pengembangan Aplikasi Client/Server dengan Borland Delphi. Jakarta : PT.Elex Media Komputindo.

Wahid, Fathul. 2004. Dasar-Dasar Algoritma dan Pemrograman. Yogyakarta : Andi. 
Masih Musliatun, Haruno Sajati, Yuliani Indrianingsih 